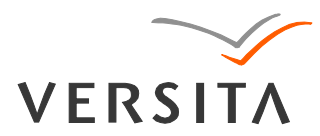

GEOCHRONOMETRIA 41(2) 2014: 129-135

DOI 10.2478/s13386-013-0149-y

Available online at

www.springerlink.com

\title{
THE APPLICATION OF THE TREE-RING CHRONOLOGIES IN ASSESSING ECOLOGICAL REQUIREMENTS OF METASEQUOIA GLYPTOSTROBOIDES GROWING IN SOUTHERN POLAND
}

\author{
SŁAWOMIR WILCZYŃSKI ${ }^{1}$, ELŻBIETA MUTER ${ }^{2}$ and BOGDAN WERTZ ${ }^{3}$ \\ ${ }^{1}$ University of Agriculture in Krakow, Faculty of Forestry, Department of Forest Protection, Entomology and Forest Climatology, \\ Al. 29 Listopada 46, 31-425 Cracow, Poland \\ ${ }^{2}$ University of Agriculture in Krakow, Faculty of Forestry, Forest Biodiversity Institute, Al. 29 Listopada 46, 31-425 Cracow, Poland \\ ${ }^{3}$ University of Agriculture in Krakow, Faculty of Forestry, Department of Biometry and Forest Productivity, \\ Al. 29 Listopada 46, 31-425 Cracow, Poland
}

Received 3 July 2013

Accepted 2 December 2013

\begin{abstract}
Metasequoia glyptostroboides is considered to be a species highly resistant to harmful environmental factors. For this reason it has been introduced to the cities. The climate of Krakow differs from that in its natural range in China. The research was focused on 40 -year-old trees, planted in Kraków on fertile alluvial soils with a low level of ground water, in the vicinity of the steelworks. During the period of the highest level of air pollution in the 1970s and 1980s, the radial increment of investigated trees showed an increasing trend. At the end of the 1980s, when the emissions were reduced, a decreasing trend in radial growth was recorded. Throughout the entire period of their life the investigated trees have shown high homogeneity of short-term growth reactions. The sensitivity chronology of the trees was characterized by a high representativeness and a strong high-frequency signal. This may indicate that the investigated trees have shown a large sensitivity to climatic factors.

The positive effect on the radial growth of Metasequoia had a cold September in the previous year, and also a cold January, April and May in the year of ring formation. Positive impact on the growth of trees had also the high precipitation occurring in April and August, as well as high air humidity in the spring of the year of ring formation. In the period 1974-2011 fifteen signature years were found. The analysis of the climatic conditions in these years confirms the results of the statistical analyses.
\end{abstract}

Keywords: tree-ring, dendroclimatology, dendroecology, Metasequoia glyptostroboides, Poland.

\section{INTRODUCTION}

Until the 1940s Metasequoia was known only as a fossil (Hu, 1946 and Merrill, 1948). In 1941 live trees were found and in $1946 \mathrm{Hu}$ (1948) decided that they belonged to Metasequoia genus. A year later Elmer Merrill (Arnold Arboretum USA) organized a trip to China in

Corresponding author: S. Wilczyński

e-mail: rlwilczy@cyf-kr.edu.pl

ISSN 1897-1695 (online), 1733-8387 (print)

(C) 2013 Silesian University of Technology, Gliwice, Poland

All rights reserved. order to obtain Metasequoia seeds. Together with a Chinese botanist $\mathrm{Hu}$, he sent the seeds around the globe to reproduce the species. In 1948, paleontologist Ralph Chaney studied natural stands of Metasequoia and gave it the English name of "Dawn Redwood". At the same time, Cheng and Hu gave it a Latin name of Metasequoia glyptostroboides (Hu and Cheng, 1948; Gittlen, 1998).

In the Tertiary period, Metasequoia genus spread throughout the forests of North America and Eurasia 
(Yang and Jin, 2000 and LePage et al., 2005). Due to climate cooling, the range of Metasequoias has been shrinking and now it grows only in isolated areas of the central-eastern China, in the zone from 400 to $2000 \mathrm{~m}$ a.s.l. (Li, 1953; Zan, 1971). This area is characterized by a relatively mild climate with abundant precipitation during growing season (Białobok, 1949; Tang et al., 2011). These long-life, coniferous trees grow in valleys, close to watercourses and on moist soils, as well as on mountain slopes (Chu and Cooper, 1950 and Bartholomew et al., 1983).

In 1949, Metasequoia seeds reached Poland. They were seeded in the botanical gardens of Kraków, Warszawa and Kórnik. It should be noted that Metasequoia trees were growing on the present territory of Poland $60 \mathrm{mln}$ years ago (Seneta and Dolatowski, 2002). Research on cultivations of this species in Poland showed that it is growing fast at medium fertile and fresh soils and in a sunny exposure (Czekalski, 1982). In turn, on alkaline and dry substratum it grows slowly. Most suitable for this species are boggy soils, formed from lowland bogs. With too high and very low levels of ground water the radial growth of trees is weaker. Level of ground water was the main factor, which determined the rate of Metasequoia growth (Bugała, 1983).

Metasequoia has been a subject of relatively numerous research works. The most recent studies, among others, concerned the natural occurrence in China ( $\mathrm{Fu}$ and Jin, 1992; Leng et al., 2007), ecology (Li and Ban, 1989; Williams et al., 2003; Williams, 2005; You et al., 2008), biology and genetics (Kuser et al., 1997; Chen et al., 2003; Yang, 2005), as well as the effect of changes in Metasequoias' environment on the population structure (Tang et al., 2011). This species has also been used in studies of climate by analyzing the content of stable isotopes (Ballantyne et al., 2006; Yang et al., 2011).

However, no results of dendrochronological research on this species has been published so far. Knowledge of the Metasequoia requirements and growth in Polish climatic conditions is relatively modest and results mainly from observing the growth of a small number of trees planted in Poland since the end of 1940s.

The aim of the paper was a dendrochronological study of the Metasequoia, consisting of the 18 individuals at age 40 years. This is the second generation of this species in Poland. The seedlings originated from seeds of trees that have been growing since 1949 in the Botanical Garden in Krakow.

The objectives of the study were:

1) The construction of site tree-ring width chronology, sensitivity chronology and proportion chronology of Metasequoia glyptostroboides.

2) The assessment of homogeneity of short-term incremental reactions, strength of high frequency signal and representativeness of chronology.
3) The analysis of radial increments in the period of intensified industrial emissions and after their reduction.

4) Identifying climatic factors which influenced radial increments.

5) Determination of signature years and identification of climatic factors which contributed to their occurrence.

\section{METHODS}

\section{Tree-ring data}

The increment cores were collected from 18 trees aged 40 , one per each tree, at a height of $1.3 \mathrm{~m}$ above the ground. The trees were growing on a fertile Mollic Gleysol, with a low ground water table $(2 \mathrm{~m})$. The study site was situated about $3 \mathrm{~km}$ from the Krakow Steelworks which started operating in 1954. Tree-ring widths were measured with an accuracy of $0.01 \mathrm{~mm}$ and the dating was verified by COFECHA program (Holmes, 1986). No missing or double rings were observed, annual rings were relatively wide and distinct.

\section{Statistical analysis}

The tree-ring width series of each tree were standardized. The annual sensitivity $c$ index was calculated for each year, according to the formula:

$$
c_{i}=\frac{2 \times\left(x_{i}-x_{i-1}\right)}{\left(x_{i}+x_{i-1}\right)}
$$

where $x_{i}$ is the tree-ring width in year $i$ and $x_{i-1}$ is the treering width in the previous year (Douglass, 1920; Fritts, 1976). The aim of the standardization was removing nonclimatic trends due to age and size of trees as well as emphasizing year-to-year variability.

In each year, the annual sensitivity indices of 18 trees were averaged, creating site chronology of annual sensitivity. In a similar way, by averaging the widths of treerings, site tree-ring width chronology was calculated.

The degree of homogeneity of the short-term incremental reaction among the trees was assessed based on the value of $r_{\mathrm{bt}}$, the mean correlation coefficient between sensitivity series of trees (Briffa and Jones, 1990).

The calculated signal-to-noise ratio (SNR) expresses high-frequency signal strength in chronology and is a measure of its quality (De Witt and Ames, 1978; Briffa and Jones, 1990). The Expressed Population Signal (EPS) was calculated as well. The EPS allows assessing the representativeness of constructed chronologies (Wigley et al., 1984; Briffa and Jones, 1990). The average relative difference in the radial increment of trees was evaluated with the use of mean sensitivity (MS) (Douglass, 1920; Fritts, 1976).

Climatic factors affecting the radial growth variability were determined by the method of bootstrap correlation analysis. This method is particularly useful when a series 
of tree ring widths and climatic data are short. Correlation coefficients between sensitivity chronology and monthly climatic data were calculated using the program DendroClim2002 (Guiot, 1991; Biondi and Waikul, 2004). The program generates 1000 bootstrap samples to estimate correlation coefficients and test their significance at $95 \%$ confidence level. The method of forward evolutionary intervals was used: analyses started for the 1975-2000 interval $(\mathrm{n}=26)$ and finished for the 1975-2011 interval $(\mathrm{n}=37)$. The analyses of climate-growth relation included: mean $\left(T_{\text {mean }}\right)$, maximum $\left(T_{\max }\right)$ and minimum $\left(T_{\min }\right)$ monthly temperatures, monthly total precipitations $\left(P_{\text {tot }}\right)$, and mean monthly relative humidities $\left(\% H_{\text {mean }}\right)$. The climatic window covered the period between September of the previous year and September of the year of ring formation $(\mathrm{n}=13)$. The percentage agreement coefficient $G L[\%]$ was used to evaluate the similarity of chronology (Eckstein and Bauch, 1969; Fritts, 1976).

To assess the level of homogeneity of short-term incremental reactions in particular years, the proportion ratio $(P)$ was used, which is applied to determine the signature years in climate-growth relation studies (Kelly et al., 1989, 2002; Spain and Pilcher, 1994; Hughes et al., 2001; Wilczyński, 2004). $P$ indicates the percentage of trees that have increased radial growth in a given year in relation to the growth of the previous year. Based on the $P$ value, signature years were determined. It was assumed that 100 percent of trees $(P=100 \%)$ increased their increment in a positive signature years, whereas all trees decreased their increment $(P=0 \%)$ in a negative signature years. The climatic conditions in positive and negative signature years were compared in order to identify climatic factors which had contributed to the occurrence of signature years.

\section{Climate of the research area and climatic data}

Climatic data were obtained from the database of the meteorological station of the Jagiellonian University in Kraków $\left(50^{\circ} 04^{\prime} \mathrm{N}, 19^{\circ} 58^{\prime} \mathrm{E}\right.$; $206 \mathrm{~m}$ a.s.l.). The station is located $4 \mathrm{~km}$ from the study site. The climatic data from the Lichuan meteorological station $\left(30^{\circ} 18^{\prime} \mathrm{N}\right.$; $108^{\circ} 57^{\prime} \mathrm{E}$; $1075 \mathrm{~m}$ a.s.1.) (natural range of Metasequoia) were taken from the publication by Tang et al. (2011) and from a webpage en.climate-data.org (Fig. 1). The mean annual temperature in Kraków amounts to $8^{\circ} \mathrm{C}$, and the total annual precipitation oscillates at the level of $675 \mathrm{~mm}$. The mean annual temperature in the natural range of Metasequoia in China reaches $13^{\circ} \mathrm{C}$, whereas total annual precipitation exceeds $1400 \mathrm{~mm}$. However, the monthly temperature and precipitation distribution during the year in both regions is very similar. The lowest temperatures and precipitations occur in the winter, and the highest in the summer. In Kraków the mean January temperature falls below zero $\left(-1.8^{\circ} \mathrm{C}\right)$, while in the Lichuan station it is above zero $\left(2.8^{\circ} \mathrm{C}\right)$. The highest mean temperature in Kraków occurs in July $\left(19.1^{\circ} \mathrm{C}\right)$, and in Lichuan in August $\left(23.9^{\circ} \mathrm{C}\right)$. In Kraków, during the growing season precipitation is about two times lower than in the place of natural occurrence of Metasequoia. In turn, the monthly relative humidity in Krakow varies from $70 \%$ to $84 \%$, and is similar to that in Lichuan (81-84\%).

\section{RESULTS}

The mean height of trees aged 40 years was $21 \mathrm{~m}$, and the mean diameter at breast height $51 \mathrm{~cm}$. The mean treering width in the years 1974-2011 amounted to $6 \mathrm{~mm}$, while the largest annual increments exceeded $13 \mathrm{~mm}$. Trees had well-developed crowns and their length ex-

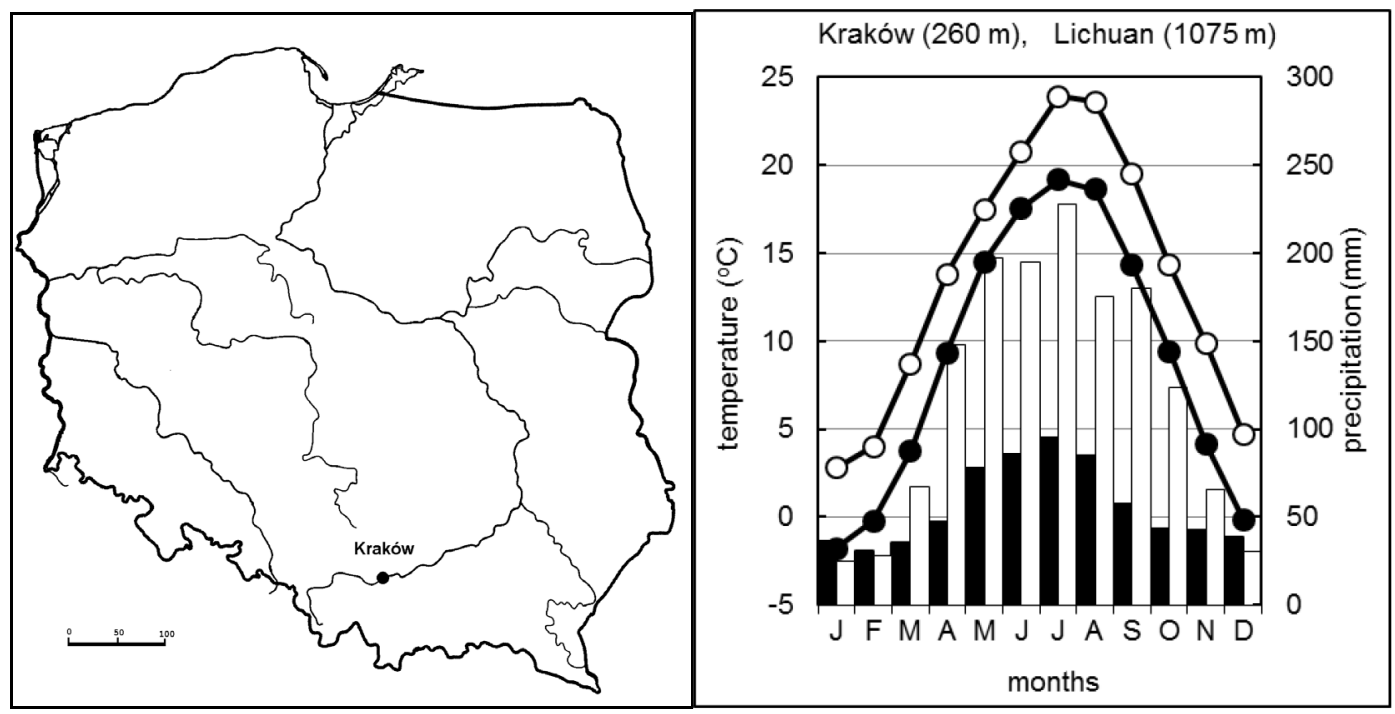

Fig. 1. The location of research area in Poland. The climatic diagram of meteorological stations in Kraków (Poland) and Lichuan (China - the natural range of Metasequoia) for the period 1960-2011. Mean monthly temperature (dots) and monthly total precipitation (bars) for Kraków (black dots and bars), and for Lichuan (white dots and bars). 
ceeded $75 \%$ of the tree height. In the period of the highest level of pollutants emitted from a nearby steelworks (1970s and 1980s) the trees showed no growth decline. At the end of the 1980s, when the emission level has decreased, a downward trend in radial growth occurred in the analyzed trees (Fig. 2). There seems to be a natural incremental trend associated with increasing age and size of the trees.

Sensitivity chronology showed a reduced long-term trends and enhanced short-term variability (Fig. 2). This has been confirmed by a relatively low value of correlation coefficient with tree-ring width chronology $(r=0.36$, $p<0.05)$ as well as a very high value of the agreement coefficient $G L=94.6 \%(p<0.001)$. The study trees displayed high homogeneity of yearly growth reaction. Sensitivity chronology was characterized by high representativeness, strong high-frequency signal and high mean sensitivity, as indicated by high values of statistics: $r_{\mathrm{bt}}=0.704, E P S=0.977, S N R=42.8$ and $M S=0.25$. This demonstrated the high susceptibility of the study species to short-term environmental incentives (stimuli).

Results of correlation analysis between the sensitivity chronology and various climatic parameters indicates that a positive impact on Metasequoia radial growth had a cold September of the previous year, as well as a cold January, April and May of the year of ring formation (Fig. 3). A positive effect on the growth of trees had also high precipitation occurring in April and August, and high air humidity in April and May in the year of ring formation.

In order to verify the results of statistical analyses an additional analysis of the climatic reasons for the occurrence of signature years was conducted. In the period 1974-2011 15 signature years were found: 7 positive $(P=100 \%)$ and 8 negative $(P=0 \%)$ (Fig. 4$)$. The years of high increment reaction homogeneity intertwined with the years of lower homogeneity. The sensitivity and proportion chronologies had similar pattern. The $G L$ agreement coefficient of both chronologies amounted to $92 \%$ $(p<0.001)$. However, not in every year did the high sensitivity values correspond to high values of proportion ratio. Thus, high homogeneity of increment reactions was not always associated with the strong incremental reactivity.

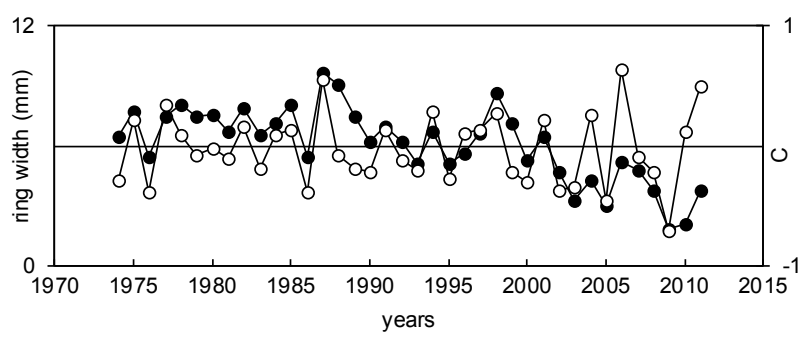

Fig. 2. The tree-ring width chronology (black dots) and sensitivity chronology (white dots).
The comparison of climatic conditions in the positive and negative signature years confirmed the results obtained by correlation method. The analysis of climatic diagrams showed that after cold and dry autumn (September, October) usually a positive signature year occurred (Fig. 5). In the positive years January was frosty,
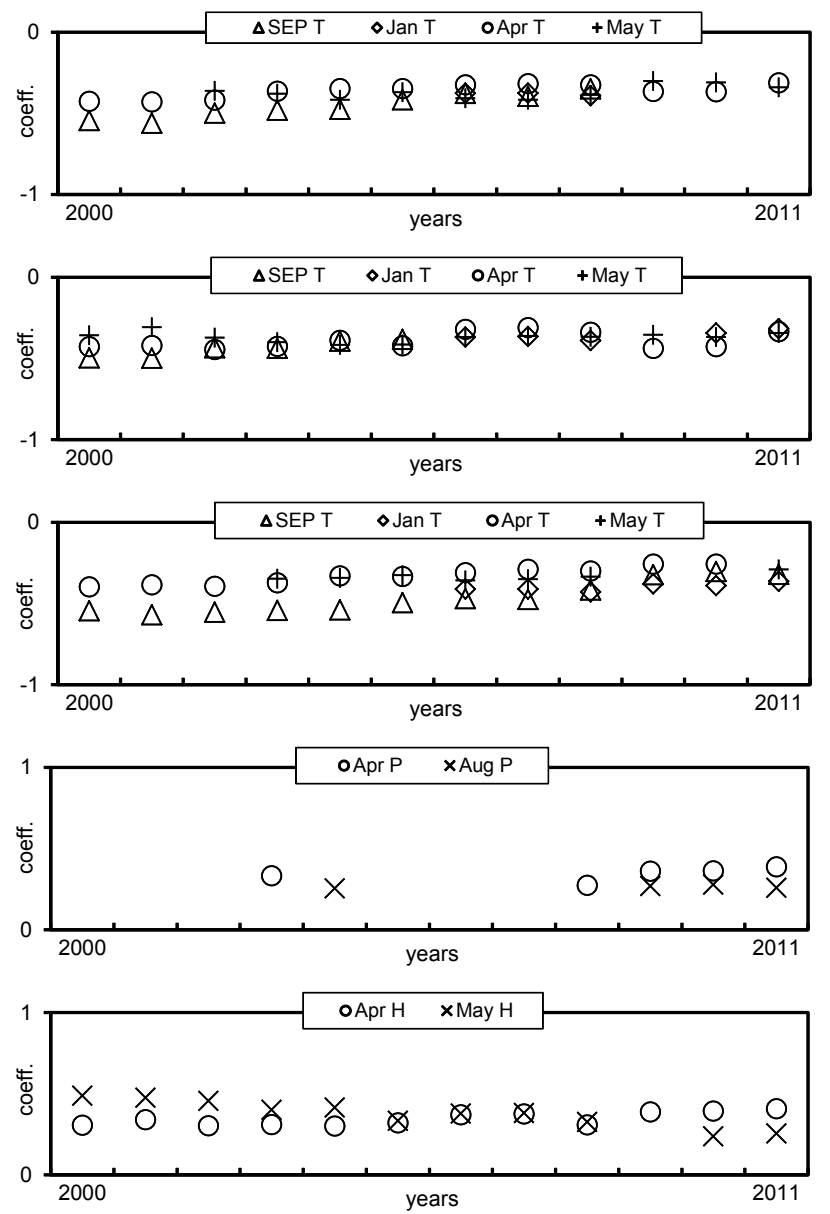

Fig. 3. The significant bootstrap correlation values $(95 \%$ confidence interval) for forward evolutionary intervals for the sensitivity chronology. The predictors are monthly precipitation $(P)$, temperature $(T)$, and relative humidity $(H)$ from September of the previous year (SEP) to September of the year of ring formation (Sep).

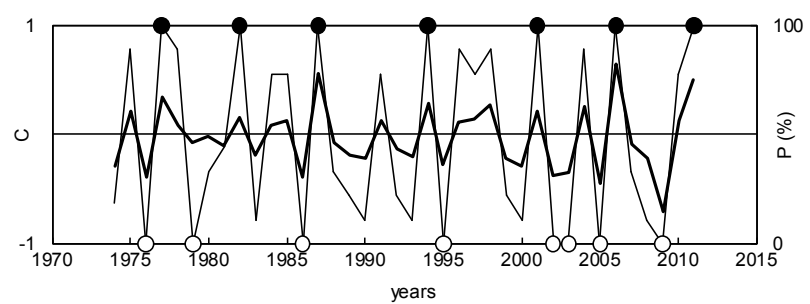

Fig. 4. The sensitivity chronology ( $\mathrm{C}-$ thin line), and the proportion chronology ( $P-$ bold line). The positive signature years were marked as black dots, and the negative ones as white dots. 
spring (April and May) was cooler and more humid, the second half of summer was humid as well; and April, June and August abounded in rainfall. In the negative signature years the climatic conditions in the abovementioned months were the opposite.

\section{DISCUSSION}

The construction of site tree-ring width chronology was relatively easy. The annual rings were distinct and wide, and the timber was free of defects. Additionally, trees displayed high homogeneity of increment reactions from year to year. Consequently, sensitivity chronology revealed a strong high frequency signal. Thus, the investigated trees displayed high sensitivity to short-term impulses from the environment.

Metasequoia is considered to be a species with high resistance to air pollution (Hrynkiewicz-Sudnik et al., 1999), and should therefore be grown in cities, as well as in industrial regions (Lukasiewicz, 1995). Investigated trees did not show symptoms of slower growth, although over 20 years they grew in the area strongly contaminated by pollutants. This may be due to the fact that trees of this species drop their short shoots with needles at the beginning of winter, and therefore they get rid of pollutants. It is recommended to assume Metasequoia plantations and bioenergy crops due to fast increment of trees (Surmiński and Bojarczuk, 1973; Monteuuis et al., 1987). Dimen-
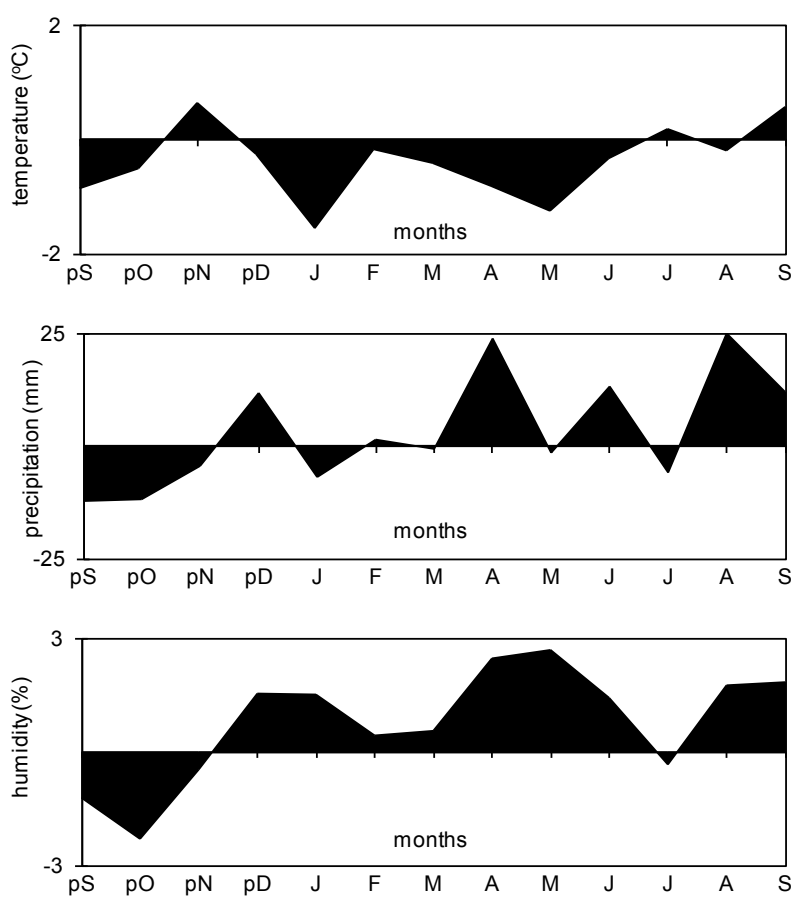

Fig. 5. The differences of mean monthly temperature, precipitation and relative humidity in the positive and negative signature years. The climatic window included the months from September of previous year (pS) to September of current year (S). sions of Metasequoia exceed the dimensions of the fastgrowing native tree species. An example is an alder ( $\mathrm{Al}$ nus glutinosa) which at the age of 40 in optimal habitat reaches the height of $22 \mathrm{~m}$ and breast height diameter of $23 \mathrm{~cm}$; and also larch $-21 \mathrm{~m}$ and $22 \mathrm{~cm}$, respectively (Szymkiewicz, 2001). Although the height of both these species is similar to the height of Metasequoia, they have a diameter smaller by over $50 \%$, and even smaller volume. It should be added, that growth parameters of Metasequoia analyzed in this paper are similar to the parameters of Metasequoia in natural environment in China (Tang et al., 2011).

A significant factor affecting radial increments of Metasequoia were the weather conditions in autumn prior to the year of growth. Trees usually finish their diameter increment at the end of August and concentrate on accumulating food reserves in September (Ermich, 1963). This has an impact on the condition and vitality of trees during the winter. The weather conditions in September also influence the quantity and quality of vegetative buds and thus on the amount of new shoots and leaves. The weather of this period also determines the quality of generative organs' buds (Chałupka, 1975; Hejnowicz, 1982). In turn, flowering and seed crop have a negative influence on radial growth (Eis et al., 1965; Chałupka et al., 1975, 1976). The results of our study indicate that cold and dry autumn has a positive effect on Metasequoia increment in the next year. We suppose that such weather conditions have a positive effect on accumulation of food reserves by trees and also the quality of vegetative organs' buds. Similar dependencies have been found in other native conifer tree species (Wilczyński, 2010).

In Poland, Metasequoia is an introduced species which achieved the second level of acclimatization. Admittedly the seedlings are frost-sensitive, but after reaching 1 meter of height, they become completely resistant to cold (Hrynkiewicz-Sudnik et al., 1999). This is confirmed by the results of our research. A strong negative correlation between radial increment and January temperature indicates that after frosty winters trees are growing better in the coming growing season. It should be added that January in Poland is usually the coldest month in the year. Similar dependences have been found in Salix alba (Wilczyński and Podlaski, 2005). Metasequoia radial growth was limited also by dry and warm spring. These relations are biologically reasonable. With the development of shoots and leaves, the tree transpiration increases strongly, and spring is often warm and dry in Poland. It increases the transpiration and leads to water shortage in trees. In turn, high air humidity decreases transpiration and relieves the effects of water shortages in soil. It was also found a high sensitivity of Metasequoia to water shortages in the early spring and late summer. This is due to the fact that in spring precipitation are often low, and in the second half of the summer frequently comes to considerable decrease of the groundwater level (Holstener-Jorgensen, 1967). In addition, the groundwater level 
on the research site was generally low. It was also noticed that the sensitivity of Metasequoia to water shortages in soil increased with age. It results from the fact that transpiration surface of the trees grows with age. Metasequoia is a fast-growing species, therefore the problem may intensify with time.

Finally, it is worth adding that another advantage of Metasequoia is its timber which can be widely used for a variety of purposes. It is light and can be easily processed. It can be used in the manufacture of sport equipment, model making as well as in pulp and paper industry (Surmiński and Bojarczuk, 1973). It is also durable and decay resistant and may therefore be used in construction industry (Kuser, 1983).

\section{CONCLUSIONS}

Results of radial increment analyses confirmed that Metasequoia is highly resistant to industrial pollution. Despite the high level of pollution occurring in the Kraków Steelworks area in the 1970s and 1980s, the investigated trees are characterized by a high sensitivity to various climatic factors. The tree increment limiting factor is a warm and humid autumn of the previous year, as well as warm winter and warm and dry spring in the year of ring formation. Also the shortages of humidity in spring and summer are limiting radial increment of trees. The negative influence had probably also a low groundwater level of site, on which grew investigated trees. This, nevertheless, never prevented trees from forming rings.

Metasequoias investigated in this study were fast growing trees. They had long and evenly developed crowns. Trees were characterized by a homogeneous pattern of tree-ring widths from year to year, and sensitivity chronology showed strong high frequency signal. The study showed that the trees have adapted to a relatively warm and humid, urban climate of Kraków. Apart from resistance to pollution, the trees also have a nice habit and attractive, seasonal variability in the color of needles. The species should therefore be planted in industrial and urban areas because undoubtedly it constitutes an interesting and decorative element of the city environment.

\section{ACKNOWLEDGEMENTS}

The study was conducted of the Agricultural University in Kraków and was financed by the Ministry of Science and Higher Education.

\section{REFERENCES}

Ballantyne AP, Rybczynski N, Baker PA, Harington CR and White D, 2006. Pliocene Arctic temperature constraints from the growth rings and isotopic composition of fossil larch. Palaeogeography, Palaeoclimatology, Palaeoecology 242 (3-4): 188-200, DOI 10.1016/j.palaeo.2006.05.016.
Bartholomew B, Boufford DE and Spongberg SA, 1983. Metasequoia glyptostroboides - its present status in central China. Journal of Arnold Arboretum 64: 105-128.

Białobok S, 1949. Metasequoia - jeszcze jedna żyjąca kopalina (Metasequoia - one more living fossil). Wszechświat 1: 23-25 (in Polish).

Biondi F and Waikul K, 2004. DENDROCLIM2002: A C++ program for statistical calibration of climate signals in tree-ring chronologies. Computers \& Geosciences 30(3): 303-311, DOI 10.1016/j.cageo.2003.11.004.

Briffa KR and Jones PD, 1990. Basic Chronology Statistics and Assessment. In: Cook ER, Kairiukstis LA, eds., Methods of Dendrochronology: Applications in the Environmental Sciences. Dordrecht: Kluwer Academic Publishers: 137-152.

Bugała W, 1983. Metasequoia glyptostroboides - 35 lat uprawy w Arboretum Kórnickim (Metasequoia glyptostroboides - 35 years practicing in Arboretum Kórnickie). Arboretum Kórnickie 28: 101-112 (in Polish).

Chałupka W, 1975. Wplyw czynników klimatycznych na urodzaj szyszek u świerka pospolitego (Picea abies (L.) Karst.) w Polsce (Influence of climatic factors on cone crops of spruce (Picea abies (L.) Karst.) in Poland). Arboretum Kórnickie 20: 213-225 (in Polish).

Chałupka W, Giertych M and Królikowski Z, 1975. The effect of cone crops on growth in Norway spruce (Picea abies (L.) Karst.). Arboretum Kórnickie 20:201-212.

Chałupka W, Giertych M and Królikowski Z, 1976. The effect of cone crops on growth in Scot pine on tree diameter increment. Arboretum Kórnickie 21: 361-366.

Chen XY, Li YY, Wu TY, Zhang X and Lu HP, 2003. Size class differences in genetic structure of Metasequoia glyptostroboides $\mathrm{Hu}$ et Cheng (Taxodiaceae) plantations in Shanghai. Silvae Genetica 52: 107-109.

Chu KL and Cooper SW, 1950. An ecological reconnaissance in the native home of Metasequoia glyptostroboides. Ecology 31(2): 260-277, DOI 10.2307/1932391.

Czekalski M, 1982. Metasekwoja chińska (Metasequoia Chinese). Ogrodnictwo 7: 194.

De Witt E and Ames M, 1978. Tree-ring chronologies of eastern North America. Chronology Series 4, Laboratory of Tree-Ring Research, University of Arizona, Tucson.

Douglass AE, 1920. Evidence of climate effects in the annual rings of trees. Ecology 1(1): 24-32, DOI 10.2307/1929253.

Eckstein D and Bauch J, 1969. Beitrag zur Rationalisierung eines dendrochronologischen Verfahrens und zur Analyse seiner Aussagesicherheit (Contribution to the rationalization of a dendrochronological method and the analysis of its reliability). Forstwissenschaftliches Centralblatt 88: 230-250 (in German).

Eis S, Garman H and Bell LH, 1965. Relation between cone production and diameter increment of Douglas fir (Pseudotsuga menziesii (Mirb.) Franco), Grand fir (Abies grandis (Dougl.) Lindl.) and Western white pine (Pinus monticola Dougl.). Canadian Journal of Botany 43(12): 1553-1559, DOI 10.1139/b65-165.

Ermich K, 1963. The inception and the end of the annual tree-ring formation in Fagus silvatica L., Abies alba Mill., and Picea excelsa L. in Tatra Mountains. Ekologia Polska Seria A 11(13): 311336.

Fritts HC, 1976. Tree Rings and Climate. Academic Press, New York: $567 \mathrm{pp}$.

Fu LG and Jin JM, 1992. China Plant Red Data Book: Race and Endangered Plants. Science Press, Beijing: 736pp.

Gittlen W, 1998. Discovered alive. The Story of the Chinese Redwood. Pierside Publications Berkeley Frankfort.

Guiot J, 1991. The bootstrapped response function. Tree Ring Bulletin 51:39-41.

Hejnowicz A, 1982. Budowa i rozwój wegetatywnych pąów sosny zwyczajnej Pinus sylvestris L. (Construction and development of vegetative buds of Scots pine (Pinus sylvestris L.). Instytut Dendrologii PAN, Kórnik.

Holmes RL, 1986. Quality control of crossdating and measuring. A users manual for program COFECHA. In: Holmes RL, Adams RK and Fritts HC, eds., Tree-ring chronologies of western North 
America: California, Eastern Oregon and Northern Great Basin. Chronology Series 6, Tucson. University of Arizona: 41-49.

Holstener-Jorgensen H, 1967. Influences of forest management and drainage on groundwater fluctuations. Forest Hydrology. In: Sopper WE, Lull HW, eds., Pergamon Press, Oxford: 325-480.

Hrynkiewicz-Sudnik J, Sękowski B and Wilczkiewicz M, 1999. Rozmnażanie drzew i krzewów nagozalażkowych (Reproduction of trees and shrubs gymnosperms). Wydawnictwo Naukowe PWN: 355357 (in Polish).

$\mathrm{Hu} \mathrm{HH}, 1946$. Notes on a Palaeogene species of Metasequoia in China. Bulletin of Geological Society of China 26: 105-107, DOI 10.1111/j.1755-6724.1946.mp26001005.x.

Hu HH, 1948. How Metasequoia, The "Living fossil" Was Discovered In China. Journal of The New York Botanical Garden 49(585): 201-207.

$\mathrm{Hu} \mathrm{HH}$ and Cheng WC, 1948. On the new family Metasequoiaceae and on Metasequoia glyptostroboides, a living species of the genus Metasequoia found in Szechuan and Hupeh. Bulletin of the Fan Memorial Institute of Biology, N. S. L. 161: 1-2.

Hughes MK, Kuniholm PL, Eischeid JK, Garfin G, Griggs CB and Latini C, 2001. Aegean tree-ring signature years explained. TreeRing Research 57: 67-73.

Kelly PM, Leuschner HH, Briffa KR and Harris IC, 2002. The climatic interpretation of pan-European signature years in oak ring-width series. The Holocene 12(6): 689-694, DOI 10.1191/0959683602hl582rp.

Kelly PM, Murno MAR, Hughes MK and Goodess CM, 1989. Climate and signature years in Western European oaks. Nature 340(6228): 57-60, DOI 10.1038/340057a0.

Kuser J, 1983. Inbreeding depression in Metasequoia. Journal of the Arnold Arboretum 64: 475-481.

Kuser JE, Sheely DL and Hendricks DR, 1997. Genetic variation in two ex situ collections of the rare Metasequoia glyptostroboides $(\mathrm{Cu}-$ pressaceae). Silvae Genetica 46: 258-264.

Leng Q, Fan SH, Li W, Yang H, Lai XL, Cheng DD, Ge JW, Shi GL, Jiang Q and Liu XQ, 2007. Database of native Metasequoia glyptostroboides trees in China based on new census surveys and expeditions. Bulletin Peabody Museum National History 48(2): 185233.

LePage BA, Yang $\mathrm{H}$ and Matsumoto M, 2005. The evolution and biogeographic history of Metasquoia. In: LePage BA, Williams CJ and Yang H, eds., The Geobiology and Ecology of Metasequoia. Springer, Dordrecht: $3-114 \mathrm{pp}$.

Li HL, 1953. Present distribution and habitats of the conifers and taxads. Morris Arboretum, University of Pennsylvania. Evolution 7: 245-261.

Li JH and Ban JD, 1989. The water fir communities endemic to China. J. Henan Normal University 4: 49-55.

Łukasiewicz A, 1995. Dobór drzew i krzewów dla zieleni miejskiej środkowo-zachodniej Polski (The selection of trees and shrubs for urban green areas in the central-western Poland). Wydawnictwo Naukowe UAM, Seria Biologiczna 53 (in Polish).

Merrill ED, 1948. A living Metasequoia in China. Science 107: 140, DOI 10.1126/science.107.2771.140.

Monteuuis O, Goubier P, Pages C, Pezet C and Sarran P, 1987. Metasequoia glyptostroboides renseignements specifiques et bouturage. Extrait des Annales Afocel: 211-253.

Seneta W and Dolatowski J, 2002. Dendrologia (Dendrology). PWN, Warszawa (in Polish)

Spain J and Pilcher JR, 1994. Signature years in European oak chronologies A.D. 1600-1750 and possible climatic causes. In: Frenzel B, red., Climatic trends and anomalies in Europe 1675-1715. Paleo- climate Research 13: 123-131.

Surmiński J and Bojarczuk T, 1973. Drewno metasekwoi chińskiej (Metasequoia glyptostroboides $\mathrm{Hu}$ et Cheng) polskiego pochodzenia (The wood metasekwoi Chinese (Metasequoia glyptostroboides $\mathrm{Hu}$ et Cheng) of Polish origin). Roczniki Dendrologiczne 27: 159-168 (in Polish).

Szymkiewicz B, 2001. Tablice zasobności i przyrostu drzewostanów ważniejszych gatunków drzew leśnych (Tables of volume and growth of stands for major forest tree species). PWRiL, Warszawa (in Polish).

Tang CQ, Yang Y, Ohsawa M, Momohara A, Hara M, Cheng S and Fan S, 2011. Population structure of relict Metasequoia glyptostroboides and its habitat fragmentation and degradation in south-central China. Biological Conservation 144(1): 279-289, DOI 10.1016/j.biocon.2010.09.003.

Wigley TML, Briffa KR and Jones PD, 1984. On the Average Value of Correlated Time Series, with Applications in Dendroclimatology and Hydrometeorology. Journal of Climatology and Applied Meteorology 23(2): 201-213, DOI 10.1175/15200450(1984)023<0201:OTAVOC $>2.0 . C O ; 2$.

Wilczyński S and Podlaski R, 2005. Klimatyczny model aktywności kambium waskularnego wierzby biatej (Salix alba L.) z Świętokrzyskiego Parku Narodowego (A climatic model of cambium vascular activity for white willow (Salix alba L.) from the Świętokrzyski National Park). Sylwan 7: 14-22 (in Polish).

Wilczyński S, 2004. Lata wskaźnikowe $i$ wyjątkowe w ocenie zwiazków przyrost radialny - klimat (The pointer and exceptional years in assessment of relationships radial growth-climate). Sylwan 5: 30 40 (in Polish).

Wilczyński S, 2010. Uwarunkowania przyrostu radialnego wybranych gatunków drzew $z$ Wyżyny Kieleckiej $w$ świetle analiz dendroklimatologicznych (Determinants of radial growth in some tree species on Kielceka Upland in light of dendroclimatological analyses). Zeszyty Naukowe Uniwersytetu Rolniczego w Krakowie 464 (341): 221pp (in Polish).

Williams CJ, 2005. Ecological characteristics of Metasequoia glyptostroboides. In: LePage BA, Williams CJ, Yang $\mathrm{H}$, eds., The Geobiology and Ecology of Metasequoia. Springer, Dordrecht: 285-304pp

Williams CJ, LePage BA, Vann DR, Tange T, Ikeda H, Ando M, Kuskabe T, Tsuzuki T and Sweda T, 2003. Structure, allometry and biomas of planataion Metasequoia glyptostroboides in Japan. Forest Ecology and Management 180(1-3): 287-301, DOI 10.1016/S0378-1127(02)00567-4.

Yang H, 2005. Biomolecules from living and fossil Metasequoia: biological and geological applications. In: LePage BA, Williams CJ, Yang H, eds., The Geobiology and Ecology of Metasequoia. Springer, Dordrecht: 253-279pp.

Yang $\mathrm{H}$ and $\mathrm{Jin} \mathrm{JH}, 2000$. Phytogeographic history and evolutionary stasis of Metasquoia: geological and genetic information contrasted. Acta Paleontology Sinica 39: 288-307.

Yang H, Liu W, Leng Q, Hren MT and Pagani M, 2011. Variation in nalkane $\mathrm{dD}$ values from terrestrial plants at high latitude: Implications for paleoclimate reconstruction. Organic Geochemistry $\quad 42(3): \quad 283-288, \quad$ DOI 10.1016/j.orggeochem.2011.01.006.

You D, Wang Z, Lei Y and Ma G, 2008. Community classification and dynamics succesion of natural forest of Metasequoia glyptostroboides Hu et Cheng. Hubei Forest Science Technology 153: 6-11.

Zan S, 1971. Na 20-lecie Metasekwoi Chinskiej (On the occasion of the 20th anniversary of the Chinese Metasequoia). Roczniki Dendrologiczne 25: 77-115 (in Polish). 